light in the only hospital along the const of a thousand miles: "During my visit here we have had twenty operations on the cye, che umputation, the removal of a large tumor and numerous tecth extracted. In medicine we have had pleurisy, tuberrulosis, totanus, small-pox, leprosy, paraplegia, different varieties of heart-lesions and otler interesting eases. In frenecology we lave the ustanl run of inflammations and displacenents, with utresia for a specialty. One of the peculiaritie's of the people liere is that they never present themselves for treatment mutil the disense is far alvanced, but of course there is an excuse for them in some anses, as they may lave suffered for years before there wis a hospital to come to. About is per cent. of the people seem to have eye trouble of some sort. Trachoma, trichiasis, ulceration and opacity are the commonest forms: vet inside a weok one meets every. thing from simple ophthalmia to panophthalmitis. In fact, one would lanve to be a specialist in every branch of medicine and surgery to do justice to the umount and range of material."

Calls are now in my hands from great cities, as well as comtry districts of Chin, Afrio, Porsin, the Philippine Islands, Egrptian Sulan, Arabin, Mexino, Turkey and Korea.

I shall be ghad to give further details to any plysician to whom this opportunity for service nppeals.

Wingert B. SMith,

Acting Candidate Secretary. Student Volunteer Movement.

125 East Twenty-Seventh Street, New York City.

\section{Dr. Shepard and the Turkish Bath}

To the Editor:-The death of Dr. Charles HI. Shepard, of Brooklyn, Oet. 29, 1010, deserves more than a passing notice, from the fact that he was literally the founder and promoter of the Turkish bath movement in this country. He was born in Ogdensburg, N. Y.. Sept. 25, 1825, and received a medical degree from the New York Medical College in 1848. In 1861 he opened, on a brond scientific basis, the first Turkish batls in Amerien, at Columbia Heights. Brooklyn. and of this he continued in active clarge up to the time of his denth.

He was a member of the American Medical Association nnd was secretary in 1893 and 1894 and (hairman in 1895 of the section now designated the Section on Preventive Medicine and l'ublic Health. For many years he contributed articles to this Section, and was one of the earliest writers in this country on the medical use of water, particularly in the form of Turkish buths. Some of his papers were translated abroad and were widely circulated as graphic presentations of the value of butlss in various diseases.

In 1876 he treated a case of hydrophobia with sucess at the Turkish buth; and this at the time attracted considernble attention, and was the subject of many theories and discussions. Dr. Shepard was one of the first men in this country to write with great positiveness on toxemias as active causes of disense, and he urged the eliminntion of toxic products through baths. Many of his enrly papers on this subject were practically forerumers of a literature that is growing constantly.

Dr. Shepard visited all the old and new baths of Europe, and mude some studies of the Turkish and Roman baths, which were embodied in lectures and papers that were highly "ppreciated at the time. At one time he knew every bath in America as well as in Europe, and what was being done there, and was an alviser to the managers. His persistent efforts urging the use of the baths has brought them into popularity in all large sumatoriums and in some insune asylums.

It is mulerstool that Dr. Shepard left " hurge muss of mannseript on the Turkish bath and on his experience of over fifty years, which will be published in the future. He died from heart failure, after a short period of invalidism, and his body was cremated, ac'ording to his wish.

\section{T. D. Crotuens, M.D., Hartford, Conn.}

\section{Electricity in Poliomyelitis}

To the Editor:-Dr. 'Theodore Diller, commenting on Dr. $\mathrm{B}$. Sach's paper of October 22, takes up the trentment of electricity (Tue Jovinar, Nov. 5, 1910, p. 1663), and condemns its use in poliomyelitis. If other medical colleges teach as much nbout electricity and its medical uses as tle one I attended their graduates had something to learn after leaving college. I wish to protest aguinst the condemnation of this most use ful agent, which at times gives almost magical results even when abused in its use. If one forgets the dose of a medicament or takes up one with which he is unfamiliar, he looks in a "dose" book and prescribes accordingly. If the drug is a liquid it is usually dissolved in an alcoholic solution (and alcohol has been known to make people forget they ever had "pain).

When it romes to the use of electricity, either medicinally or commercially, there is more thun one modality. In medicine the induced (farudie) current, the continuous (galvanic) current, given first direct and then make and break on the opposite pole. the static breeze and sparks, during the administration of which the little patient cun be held in the nurse's arms; the motor wave current; then the high-frequency or step-up voltage from either the static or coil, give results that can be seen diry to day.

Massage stimulates the nerves where they are kneaded; braces imprison already enervated muscles and thus diminish their size and use; transplantation of nerves or muscles lelps in some instances. To use electricity requires time and patience; and if those who have neither of these condemn its use indiscriminately it shows lack of something. The fact that there are so many veiled references to it in literature is proof enough that there is virtue in the use of electricity.

The proper way to ascertain its value for definite presentation would be for the American Mredical Association or the Ameriean Electrotherapentic Association to appoint a committee to which scientists outside of medicine could furnish evidence and data not obtainable by the medical man and that would be authoritntive.

Almerin W. Bafr, Ph.G., M.D., Clicago.

\section{The Nasal Spatiometer: A Suggested Name for Dean's Septimeter}

To the Editor:-I have just read with interest an article in Tue Jolnknal (Nov. 26. 1910, p. 1858) by Dr. L. W. Dem, on "Clinges in the Nose After Widening the Palatal Arell." It seems to me that Jr. Dean would attract more attention to his septimeter and to his particular line of investigntion were lie to give his instrument another name. There are septometers on the market. In fact, I described a nasal septometer in the New York Medical Journal, July 13, 1901. A nasal septometer is an instrument devised to measure the nasal septum, its thickness at any point. Dr. Dean's instrument was designed to measure, not the septum, but the distance between the septum and the turbinate bone; it might just as well be ealled a turbinometer. Now were he to name his instrument a "nasal sputiometer" he would more definitely describe the use of his device. The coined word is derived from the Latin words, spatium, "a space or distance." and melrum, "a measure." 1 think that Dr. Dean is entitled to diflerentiate his new device from an instrument that has been on the market for years.

Henky Waldace, Glen Ridge, N. J.

\section{Phenol in Herpes}

I'o the Editor:-For the past four years I love treated herpes with an application of a 95 per cent. solution of phenol. As soon as the skin begins to turn white I neutralize the phenol effert with alcolol. In many cases one application suffices; in no ease is it necessary to make more than three applications. After one application of the 95 per cent. phenol I dress the lesions with a simple ointment like zinc oxid. It is surprising how quickly it will relieve the pain, itching and burning. The vesicles shrivel and dry up in a very short time lenving a dry crust. I first used it in herpes progenitalis with such satisfactory results that I was led to try it for herpes zoster, in which it gave equally satisfactory results. Looking over the literature of herpes, I have not been able to find phenol mentioned in its treatment.

G. P. Coopernail, Bedford, N. Y. 